\author{
Katarzyna MichaŁowsKa \\ Uniwersytet Mikołaja Kopernika \\ Katedra Języka i Cywilizacji Greckiej
}

\title{
Kryterium semantyczne w badaniach etymologicznych i językowych M.T. Warrona w świetle jego traktatu
}

\section{De lingua Latina}

Słowa klucze: Warron, etymologia, semantyka, kryterium

W warrońskich studiach nad językiem łacińskim, prezentujących najdawniejszą tradycję w rzymskich badaniach językowych i etymologicznych, niezwykle istotna okazuje się rola znaczenia. W związku z tym, że starożytni teoretycy języka nie uświadamiali sobie diachronicznego aspektu języka, uniemożliwiało im to dotarcie do pierwszych, stricte historycznych źródeł słów, i sprawiało, że poruszali się ciągle na płaszczyźnie synchronicznej, a więc porównywali słowa z tego samego systemu językowego i tym samym szukali dla nich motywacji, która nie wychodziła poza ten system, a tkwiła w obrębie tego systemu. Przy takim badaniu języka, bardzo często podstawowym kryterium badawczym było kryterium semantyczne. Stosowanie tego kryterium w badaniach językowych bardzo mocno wpłynęło na charakter ówczesnego językoznawstwa, a przede wszystkim etymologii.

Marek Terencjusz Warron (116-27 p.n.e.) był najwybitniejszym i najbardziej wszechstronnym uczonym rzymskim, który objął swą działalnością naukową szereg dziedzin życia rzymskiego. Jego zainteresowania naukowe i literackie charakteryzowało umiłowanie starorzymskiej poezji, kultury i historii Lacjum, 
a co za tym idzie także dialektów latyńskich, języka oskijskiego i sabińskiego1. Najważniejszym i zachowanym ${ }^{2}$ dziełem tego autora $\mathrm{z}$ dziedziny językoznawstwa jest traktat De lingua Latina - O języku tacińskim. Obejmował on $25 \mathrm{ksiagg,}$ w których poruszone zostały zagadnienia z trzech obszernych działów: etymologii (księgi 2-7), fleksji, czyli deklinacji i koniugacji, a dokładniej zachodzących w nich zjawisk analogii i anomalii (księgi 8-13), oraz składni (księgi 14-25). To właśnie pierwsza część tego traktatu, a zwłaszcza księgi 5-7, stały się dla nas źródłem wiedzy o pierwszych łacińskich badaniach etymologicznych. Warron opracowując swoją teorię etymologiczna, przedstawił etymologie ponad 1350 słów $^{3}$. Jego zdaniem, badanie etymologiczne miało na celu dotarcie do pierwotnego znaczenia danego słowa, a więc poszukiwanie i wyjaśnianie verbów określanych mianem primigenia, czyli słów rdzennych, lub inaczej pierwotnych, które leżą u podstaw każdego słowa. Co prawda verba primigenia są jedynie synchronicznymi odpowiednikami słów, tj. ich podstawami słowotwórczymi, jednak na uwagę zasługuje fakt, że w intencji Warrona miały to być odpowiedniki jak najdalsze, czyli najwcześniejsze historycznie i najbardziej pierwotne. Do verbów primigenia dochodzi się poprzez analizę etymologiczną tzw. declinata, czyli derywatów, które, jak słusznie zauważył Warron, stanowią większą część całego słownictwa. W analizie etymologicznej Warron ucieka się częściowo do etymologii, a częściowo do samej semantyki, ponieważ badanie nad powstawaniem pierwszych słów, czyli nad ich pierwszym znaczeniem, odbywa się często metodą przenoszenia, pomijania czy redukowania znaczeń innych terminów, z którymi dane słowo wykazuje jakieś podobieństwo semantyczne lub brzmieniowe. Pomimo tego, że w dochodzeniu do prawdy o danym

1 Dorobek twórczy Warrona obejmuje rozprawy filozoficzno-historyczne, pisma z zakresu retoryki, prawa, rolnictwa, dzieła encyklopedyczne, a także dzieła z zakresu języka. Do tej ostatniej grupy należy szereg monografii, niestety nie zachowanych: a) De similitudine verborum w 3 księgach, poświęcone analogii; b) De utilitate sermonis, poświęcone anomalii; c) De sermone Latino w 5 księgach, w których autor stara się ustalić kryteria poprawności językowej w łacinie, mowa tu także o fonetyce, zdaniach i stylach; d) De origine linguae Latinae, w 3 księgach, poświęcone pochodzeniu języka łacińskiego i jego pokrewieństwu z innymi językami: greckim (eolskim), sabińskim, oskijskim i etruskim.

2 Z całego traktatu zachowały się jedynie księgi 5-7, w których omówione zostały zagadnienia etymologiczne oraz księgi 8-10, w których traktuje się o analogii i anomalii we fleksji.

3 Ta liczba odnosi się do samego traktatu De lingua Latina. Natomiast łączna liczba etymologii przedstawionych przez Warrona we wszystkich dziełach wynosi około 1750. 
słowie rola znaczenia okazuje się niezwykle istotna, Warron wyraźnie odróżniał semantykę od etymologii, co wynika ze słów samego autora:

Ponieważ każde słowo składa się z dwóch elementów, tego, od którego pochodzi i tego, do którego się odnosi [scilicet które oznacza, a zatem z nazwy i znaczenia] [...], ta pierwsza część, która bada, skąd się biorą i jak powstają nowe słowa, nazywana jest przez Greków etymologią ( $\dot{\varepsilon} \tau v \mu o \lambda o \gamma i^{\prime} \alpha$ ), druga natomiast semantyką $(\pi \varepsilon \rho i \sigma \eta \mu \alpha \imath v o \mu \varepsilon \dot{v} v \omega v)$. Właśnie o tych dwóch zagadnieniach będę razem traktował w tych księgach, z tym, że o tym ostatnim krócej

Zacytowany fragment wyraźnie podkreśla, że z warrońskiego punktu widzenia etymologia i semantyka stanowią dwie odrębne dyscypliny naukowe, z których pierwsza bada pochodzenie słów, a druga zajmuje się analizą ich znaczenia. Różnica między nimi zostaje zarysowana w sposób bardziej dokładny, gdyż w tym samym fragmencie czytamy:

Tak więc, jeśli szukamy słowa, od którego pochodzi pertinacia ('upór, zaciętość'), okazuje się, że wywodzi się ono od pertendo ('prowadzić dalej, starać się coś przeprowadzić, upierać się przy czymś') $)^{5}$. Natomiast to, w odniesieniu do czego zostało ono utworzone [scilicet znaczenie tego słowa], staje się jasne wtedy, gdy wyjaśnimy, że pertinaciam, czyli zaciętość posiada się wtedy, gdy wytrzymujemy w czymś, w czym nie musimy, gdyż jeśli ktoś jest wytrwały w czymś, w czym musi wytrwać, mówi się o innego rodzaju wytrwałości, mianowicie o perseverantia ('wytrwałość, wytrzymałość, długotrwałość') ${ }^{6}$.

4 Wszystkie zacytowane fragmenty prezentowane są w przekładzie własnym, natomiast tekst oryginalny pochodzi z ogólnie dostępnego wydania angielskiego: Varro, De lingua Latina, edidit Roland G. Kent, t. I (V-VII), Loeb, London, 1977. De L.L., V, 2 : Cum unius cuiusque verbi naturae sint duae, a qua re et in qua re vocabulum sit impositum [...] priorem

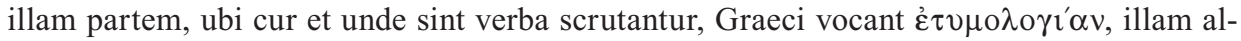
teram $\pi \varepsilon \rho \uparrow \sigma \eta \mu \alpha \imath v o \mu \varepsilon ́ v \omega v$. De quibus duabus rebus in his libris promiscue dicam, sed exilius de posteriore.

5 Etymologia podana przez Warrona jest błędna, ponieważ rzeczownik pertinacia, -ae oznaczający 'upór, wytrwałość' pochodzi nie od czasownika pertendo, -ere, tendi, tensum ('prowadzić dalej, starać się coś przeprowadzić, upierać się przy czymś'), a od przymiotnika pertinax, -acis - 'długotrwały, wytrwały, uparty'.

${ }^{6}$ Varro, De L.L., V, 2: [...] itaque a qua re sit pertinacia cum requiritur, ostenditur esse a pertenendo; in qua re sit impositum dicitur cum demonstratur, in quo non debet pertendi et pertendit, pertinaciam esse, quod in quo oporteat manere, si in eo perstet, perseverantia sit $[\ldots]$. 
Warron zauważa więc, że w etymologii badającej pochodzenie słów rola znaczenia jest na tyle istotna, że pozwala nam na dotarcie do ich źródeł. Natomiast w semantyce znaczenie słowa stanowi cel sam w sobie, tzn. semantyka służy określaniu zakresu znaczeniowego poszczególnych słów, sposobu ich używania, zakreślania ich kontekstu. Warron w swoich spostrzeżeniach semantycznych idzie o krok dalej, ponieważ zauważa, że z tym samym znaczeniem mogą się łączyć dwie formy albo i więcej, lub odwrotnie, z tą samą formą mogą pozostawać w związku dwa znaczenia. Rozróżniał zatem zjawiska synonimii i polisemii. Przykładowo z uwagą zaobserwował różnice znaczeniowe w obrębie synonimów czasownikowych agere, facere, gerere, które znaczą tyle, co 'robić, czynić, wykonywać, z tym że zakres ich użycia jest ograniczony ${ }^{7}$. Można bowiem powiedzieć poeta facit fabulam, a więc 'poeta komponuje dzieło dramatyczne', ale nie można powiedzieć poeta agit fabulam, gdyż czasownik agere w tym kontekście znaczy 'przedstawiać sztukę, grać w sztuce'. Dlatego też agere fabulam można powiedzieć tylko w odniesieniu do aktora, a więc aktor gra sztukę - actor agit fabulam, a poeta ją komponuje - poeta facit fabulam. Podobnie jest z czasownikiem gerere, który znaczy 'wykonywać', ale w sensie 'przeprowadzać, sprawować, zarządzać'. Dlatego też mówiąc imperator res geret, mamy na myśli to, że 'wódz załatwia sprawy', czyli przeprowadza ważne dla państwa działania. Jednak nie możemy powiedzieć imperator res facit lub agit, ponieważ żadne $\mathrm{z}$ tych wyrażeń nie podkreśla trudu i wagi przeprowadzanych działań w taki sposób, jak czasownik gerere. Obok wyrazów synonimicznych Warron wyróżnia także homonimy. Przykładowo zauważa, że słowo pilum może oznaczać 'pocisk' lub 'oszczep', które służą do tego, by uśmiercić wroga (peri$r e)^{8}$ albo 'tłuczek', czyli przyrząd do tłuczenia czy rozdrabniania zboża ( far pisare $)^{9}$. Przykładów na synonimię i polisemię jest jednak niewiele i, niestety, nie zostały one jednoznacznie scharakteryzowane, ani też określone expressis verbis jako zjawiska polisemii czy synonimii. Charakterystyka tych zjawisk jest raczej opisowa i pojawia się przy okazji analiz etymologicznych określonych ter-

7 Varro, De L.L., VI, 77: Tertium gradum agendi esse dicunt, ubi quid faciant; in eo propter similitudinem agendi et faciendi et gerendi quidam error his qui putant esse unum. Potest enim aliquid facere et non agere, ut poeta facit fabulam et non agit, contra actor agit et $<$ non $>$ facit, et sic a poeta fabula fit, non agitur, ab actore agitur non fit. Contra imperator quod dicitur res gerere, in eo neque facit neque agit, sed gerit, id est sustinet, tralatum ab his qui onera gerunt, quod hi sustinet.

8 Varro, De L.L., V, 116: [...] similiter ab omine pilum, qui hostis periret, ut perilum.

9 Varro, De L.L., V, 138: Pilum, quod eo far pisunt, a quo ubi id fit dictum pistrinum. 
minów. Warron zaznaczył jednak, że w księgach etymologicznych obserwacji z zakresu samej semantyki będzie niewiele, gdyż podstawowym ich celem jest analiza etymologiczna ${ }^{10}$. Niewykluczone zatem, że gdyby przedmiotem badań była tutaj sama semantyka, warrońskie obserwacje i założenia dotyczące synonimii i polisemii oraz innych kwestii z zakresu semantyki zostałyby przedstawione w sposób bardziej precyzyjny i przy użyciu właściwej terminologii.

Pomimo że Warron pragnie dotrzeć poprzez analizę etymologiczną do prawdziwych źródeł danego słowa, znaczenie słowa, które stanowi ważny element tych badań, staje się przedmiotem nadużycia i w konsekwencji może prowadzić do fantazyjności etymologii. W ten sposób właściwe badanie etymologiczne czasami zostaje wręcz podporządkowane kryterium semantycznemu, a etymologie przedstawiane przez Warrona okazują się czystą fantazją autora. Przykładowo podobieństwo znaczeniowe, a w tym wypadku także brzmieniowe, między słowem pertinacia oznaczającym 'upór' a czasownikiem pertendere 'upierać się przy czymś' okazało się wystarczająco zasadne, aby uznać pochodzenie pertinacia od pertendere za poprawne etymologicznie, podczas gdy rzeczownik pertinacia pochodzi od przymiotnika pertinax 'wytrwały, uparty'. Nie zawsze jednak podobieństwo znaczeniowe między dwoma wyrazami prowadzi Warrona do ustalania błędnych etymologii. Przykładowo w księdze VII traktatu, Warron zastanawia się nad actiones, czyli działaniami, które zachodzą w czasie i analizuje po kolei etymologie terminów określających różne rodzaje actiones ${ }^{11}$. Jedną z pierwszych i podstawowych czynności, jakich dokonuje człowiek, jest myślenie, tj. cogitare. Zdaniem Warrona, cogitare ('razem zestawiać w myśli, myśleć, rozważać') pochodzi od czasownika cogere ('składać razem'), ponieważ umysł składa wiele rzeczy w jedno, aby potem mógł z tego coś wybrać ${ }^{2}$. W tym wy-

${ }^{10}$ Varro, De L.L., V, 2; zob. supra s. 2, przyp. 4.

11 Warron rozpatruje actiones ze stoickiego punktu widzenia, dlatego też przy układaniu materiału zaczerpnął z modeli stoickich, w których obowiązywał trójpodział działań ludzkich na vó $\mu \alpha, \lambda \varepsilon \kappa \tau o ́ v, \pi \rho \tilde{\gamma} \gamma \mu \alpha$, czyli myślenie, mówienie, działanie, które u Warrona określone zostaja jako cogitare, dicere, facere. Do każdej z tych kategorii należy określone słownictwo, które Warron odpowiednio grupuje, a następnie poddaje analizie etymologicznej (zob. Varron, La langue latine. Livre VI, texte établi, traduit et commonté par Pierre Flobert, Paris: Les Belles Lettres, 1985, s. 10; H. Dahlmann, Varrone e la teoria ellenistica della lingua, presentazione, note e commento e bibliografia a cura di G. Calboli. trad. ital. di P. Vozza., Napoli: Loffredo Editore, 1997, s. 40-43. Jest to włoski przekład pracy H. Dahlmanna, której niemiecki oryginał ukazał się w 1964 roku).

12 Varro, De L.L., VI, 43: Cogitare a cogendo dictum: mens plura in unum cogit, unde eligere possit. Sic e lacte coacto caseus nominatus [...]. 
padku etymologię tę można uznać za poprawną, gdyż faktycznie istnieje związek etymologiczny między cogito, -are a czasownikiem cogo, cogere ('razem zgromadzić'). Otóż zarówno jeden, jak i drugi czasownik są złożeniami z przyimka cum oraz odpowiednio czasowników agitare i agere: cogito $<*$ coagito $<*$ cum + agito - 'razem pędzić, miotać, zestawiać'; cogo <* co-ago < *cum+ago - 'razem spędzić, zgromadzić'. Związek etymologiczny między cogitare a cogere wynika z tego, że czasownik agitare ('popędzać') pochodzi etymologicznie od czasownika agere ('pędzić, prowadzić') i wyraża większe nasilenie czynności wyrażonej przez czasownik agere ${ }^{13}$. Natomiast zupełnie fantazyjna okazuje się etymologia caseus od *cogere, ponieważ przeważyło tutaj kryterium semantyczne, a mianowicie Warron twierdzi, że forma caseus, - $i$, czyli 'ser', pochodzi od lac coactum, czyli zebranego, dosłownie ściśniętego mleka, gdzie forma coactum to participium perfectum od czasownika cogere. Obecnie etymologia słowa caseus nie jest nam do końca znana, gdyż najprawdopodobniej termin caseus, -i lub caseum, - $i$ - 'ser', z greckiego turo/v, jest terminem technicznym na -eus pochodzenia etruskiego jak puteus, -i ('dół wykopany w ziemi, studnia, kopalnia'), balteus, -i / balteum, - $i$ ('obramowanie, brzeg, pas') ${ }^{14}$. Natomiast z całą pewnością termin caseus nie ma nic wspólnego z wyrażeniem lac coactum. Podobnie czysto ludowa jest etymologia rzeczownika cura, -ae, oznaczającego 'troskę'. W glosariach termin ten thumaczony jest przez greckie غ́㇒ı $\mu \varepsilon^{\prime} \lambda \varepsilon \imath \alpha$ ('troska, urząd, piecza'), $\theta \varepsilon \rho \alpha \pi \varepsilon i ́$

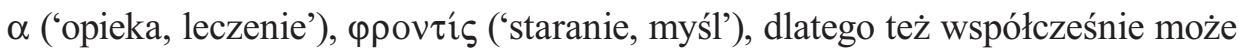
on oznaczać 'stanowisko' lub 'kuratelę' w języku prawniczym, a w medycynie 'leczenie'. Zdaniem Warrona, termin ten pochodzi od wyrażenia cor urare, czyli 'parzyć serce'15, co jest oczywistą fantazją. Należy jednak podkreślić, że była to jedna z częstszych i bardziej popularnych etymologii starożytnych, dlatego niekoniecznie jej autorem musiał być sam Warron. Współcześnie wiemy jedynie tyle, że najstarszą notowaną formą słowa cüra, -ae jest forma *koisā. Od tego rzeczownika utworzony został czasownik curo, -are ${ }^{16}$ 'troszczyć się o kogoś, o coś', którego używano przede wszystkim w sensie medycznym, np. cutem czy pelliculam curare - 'pielęgnować, leczyć skórę'. W większości języków zachowało ono swoje pierwotne znaczenie, na przykład w języku włoskim: curare ('leczyć'). Zdaniem Warrona, to rzeczownik cura pochodzi od czasownika curare, a nie na

13 Czasownik agitare uznaje się za intensivum lub frequentativum dla czasownika agere.

14 A. Ernout, A. Meillet, 1967: 114.

15 Varro, De L.L., VI, 46: Curare a cura dictum. Cura quod cor urat [...].

16 Archaiczne formy tego czasownika to coirauit, coerauit (Thesaurus Linguae Latinae, vol. IV, szp. 1495, 82). 
odwrót. To nie jedyny przykład, w którym czasowniki odrzeczownikowe Warron uznaje nie za derywaty, a za podstawy słowotwórcze.

Jak się okazuje, kryterium semantyczne było dla Warrona bardzo ważne również przy definiowaniu procesu derywacji, której wyodrębnił trzy rodzaje, tj. declinatio nominandi (deklinacja nazywania), declinatio augendi (deklinacja powiększania) i declinatio minuendi (deklinacja pomniejszania). Punktem wyjścia w tym podziale było znaczenie generowanych derywatów. Warron zauważył bowiem, że declinatio nominandi generowała derywaty o jakby innej kategorii semantycznej od tych, jakie powstają w procesie declinationis augendi i minuendi. Otóż declinatio nominandi obejmowała derywację za pomocą sufiksu (incrementum), w wyniku której mogły powstawać m.in. derywaty oznaczające miejsce, np. equile, -is ('stajnia dla koni') < equus, -i ('koń'). Declinatio augendi obejmowała natomiast derywację za pośrednictwem sufiksów (incrementum), które decydowały o większym natężeniu cechy wyrażanej przez podstawę, a dokładniej stopniowanie przymiotników, np.: albus ('biały') > albius ('bielszy'). Natomiast trzeci rodzaj declinatio minuendi to derywacja za pomocą sufiksów, w wyniku której powstają zdrobnienia, np.: cistula ('skrzyneczka') < cista ('skrzynka'). Warron, analizując znaczenie derywatów, dostrzegł, że declinatio nominandi nie generuje form, które oznaczają większe natężenie jakiejś cechy, a więc przymiotników w stopniu wyższym i najwyższym (genus augendi), ani też form oznaczających rzeczy albo osoby mniejsze od tych nazywanych wyrazem podstawowym, jak np. cista >cistula (genus minuendi). Zatem derywaty declinationis augendi i minuendi $\mathrm{w}$ pewnym sensie są do siebie zbliżone, ponieważ działają na zasadzie kontrastu, tzn. pierwsze z nich oznaczają większe nagromadzenie danej cechy w stosunku do podstawy słowotwórczej, drugie natomiast odwrotnie - mniejsze, ponieważ oznaczają rzeczy albo osoby mniejsze od tych nazywanych wyrazem podstawowym, natomiast nieistotna jest w tym miejscu kategoria fleksyjna, tzn. czy jest to rzeczownik czy przymiotnik $^{17}$. Znajduje to odbicie w samych nazwach tych rodzajów derywacji, mianowicie declinatio augendi, czyli deklinacja powiększania, oraz minuendi deklinacja pomniejszania. Natomiast derywacja określana mianem decli-

17 Stopniowanie przymiotników jest typowym przykładem zjawiska leżącego na pograniczu fleksji i słowotwórstwa. Formy albus, albius, albissimus, możemy bowiem uznać zarówno za derywaty, jak i za formy fleksyjne. Jeśli uznamy je za trzy odrębne jednostki wyrazowe, dla których podstawą słowotwórczą jest forma albus, a wykładnikami derywacji sufiksy -ius, -issimus, to wtedy zaliczymy je do słowotwórstwa. Można jednak również uznać je za formy czysto fleksyjne. 
natio nominandi generowała formy jakby innej kategorii semantycznej, gdyż nie działała tutaj zasada stopniowania natężenia cechy wyrażonej w podstawie słowotwórczej. Do derywatów powstałych w tym procesie należą rzeczowniki pospolite (vocabula) oraz nazwy własne (nomina). Podstawami słowotwórczymi (radices lub verba primigenia) w declinatio nominandi mogły być rzeczowniki pospolite, nazwy własne i czasowniki. Derywaty tworzone od rzeczowników pospolitych nazywane były declinata a vocabulo (np. ovis ('owca') > ovile ('owczarnia'), te od nazw własnych declinata a nominibus (np. Roma > Romanus; Asia $>$ Asiaticus), a te od czasowników declinata a verbo (currere ('biegać') > cursor ('goniec, biegacz').

Przedstawiony tutaj materiał egzemplifikacyjny dowodzi, że starożytne zainteresowania etymologiczne sprowadzały się raczej do spekulacji słowotwórczych, polegających na przypisywaniu wybranym nazwom określonych motywacji, a nie analiz etymologicznych w dzisiejszym tego słowa znaczeniu. O ile zadaniem współczesnej etymologii jest odtworzenie wyrazu, wykrycie przypuszczalnego pierwotnego znaczenia, wyjaśnienie jego dalszego rozwoju semantycznego i objaśnienie struktury morfologicznej, o tyle etymologii starożytnej w taki sposób zdefiniować nie można, ponieważ rzadko kiedy udało się starożytnym badaczom języka dojść w badaniu etymologicznym do faktycznej wcześniejszej formy danego słowa i jego uprzedniego znaczenia. Proces odkrywania prawdziwego pochodzenia danego słowa zamykał się w obrębie analizy słowotwórczej, ponieważ nie wskazywał na historyczne, czyli diachroniczne, odpowiedniki słów, ale na ich podstawy słowotwórcze. Związki etymologiczne między określonymi wyrazami były wyznaczane w oparciu o podobieństwo brzmieniowe zestawianych słów oraz ich podobieństwo znaczeniowe ustalane w sposób dowolny. Dlatego też tak dominująca okazała się w nich rola kryterium semantycznego. $Z$ drugiej strony trudno oczekiwać od ówczesnych gramatyków, w tym Warrona, aby opierali badanie etymologiczne na analizie porównawczej i dostrzegali semantyczność morfemów derywacyjnych, skoro wówczas nie uświadamiano sobie jeszcze diachronicznego aspektu języka i nie istniała metoda historyczno-porównawcza. Bądź co bądź, osiągnięcia starożytnego językoznawstwa, m.in. teorie Warrona, stanowią ważne ogniwo w rozwoju całej lingwistyki, w tym etymologii. 


\section{Bibliografia}

Teksty źródłowe:

M. Terenti Varronis De lingua Latina quae supersunt, edidit G. Goetz, F. Schoell, accedunt grammaticorum Varronis librorum fragmenta, Amsterdam: Hakkert, 1964.

Varron, La langue latine. Livre VI, edidit P. Flobert, Paris: Les Belles Lettres, 1985.

Varron, De lingua Latina, edidit R. G. Kent, t. 1-2, London: Loeb, 1977.

De lingua Latina, libro VI, E. Riganti testo crit., trad. e com., Bologna: Patron, 1978.

Monografie:

Cavazza F., 1981, Studio su Varrone etimologo e grammatico. La lingua Latina come modello di struttura linguistica, Firenze: La Nuova Italia.

Collart J., 1954, Varron grammairien latin, Paris: Les Belles Lettres.

Dahlmann H., 1997, Varrone e la teoria ellenistica della lingua, presentazione, note e commento e bibliografia a cura di G. Calboli. trad. ital. di P. Vozza, Napoli: Loffredo Editore.

Heinz A., 1978, Dzieje językoznawstwa w zarysie, Warszawa: Wydawnictwo Naukowe PWN.

Wilmanns A., 1864, De Terentii Varronis libris grammaticis scripsit reliquiasque subiecit, Berlin: Weidmann.

Słowniki:

ABramowiczówna Z., 1958-1965, Slownik grecko-polski, t. 1-4, Warszawa: Wydawnictwo Naukowe PWN.

Ernout A., Meillet A., 1967, Dictionnaire étymoloqique de la langue latine, Paris: Klincksieck.

PlezIA M., 1999, Stownik tacińsko-polski, t. 1-5, Warszawa: Wydawnictwo Naukowe PWN.

Thesaurus Linguae Latinae, vol. IV, 1906-1909, Lipsiae: Teubner.

WaLde A., Hofmann J. B., 1938-1954, Lateinisches Etymologisches Wörterbuch, vol. I-II, Heidelberg: Winter. 


\section{The semantic criterion in the linguistic and etymological researches of M.T. Varro in light of his work De lingua Latina}

\section{( s u m mary)}

This article presents the role of meaning in the linguistic and etymological researches of Marcus Terentius Varro, the Roman polymath and man of letters, in the light of his linguistic work De lingua Latina. The ancient theoreticians of language were not aware of diachronic linguistics and identified the concrete connections between words on the base of similarities in the sounds and in the meanings of the words being compared. For that reason, etymological and linguistic analyses of Varro very often rest on the semantic criterion which causes certain consequences for the character of his findings. 